\title{
ПІДВИЩЕННЯ ВІДМОВОСТІЙКОСТІ ФУНКЦІОНУВАННЯ ГНУЧКИХ ВИРОБНИЧИХ СИСТЕМ ЗА ДОПОМОГОЮ ПРИХОВАНИХ МАРКІВСЬКИХ МОДЕЛЕЙ
}

\begin{abstract}
Анотація: В роботі розглядається проблема відмовостійкості функціонування гнучких виробничих систем. Пропонується підхід до підвищення відмовостійкості шляхом удосконалення типової системи оперативного управління з синхронною моделлю шляхом введення прихованої марківської моделі виробництва, що володіє можливостями відновлення втрачених даних в середовищі з невизначеностями. Досліджені можливі алгоритмічні рішення по відновленню втрачених даних.

Ключові слова: гнучка виробнича система, система оперативного управління, приховані марківські моделі, автоматизований транспортний модуль.
\end{abstract}

\section{Вступ}

Моделювання гнучких виробничих систем (ГВС) широко використовуеться як на етапі проектування, так і на етапі експлуатації, зокрема, моделі ГВС є невід'ємними компонентами системи оперативного управління (СОУ) виробництва [2].

В науково-технічній літературі розглядаються різні моделі автоматизованих виробничих систем (ABC), які можна розділити на наступні категорії: ймовірнісно-аналітичні, імітаційні, сіткові (в тому числі сітки Петрі), моделі на базі теорії розкладів [1].

Щодо використання моделей ГВС на етапі експлуатації, важливими $є$ наступні чинники: можливість моделі забезпечувати виконання розрахунків на EOM в режимі реального часу, низька обчислювальна складність алгоритмів, що забезпечують процес моделювання, а також інші особливости, в залежності від специфріки поставленої задачі, що виконуеться за допомогою моделі.

Важливою задачею при організації виробництва, зокрема при проектуванні СОУ ГВС, є забезпечення надійності СОУ. Одним з запропонованих методів підвищення надійності роботи СОУ ГВС $е$ введення дублюючої синхронної моделі (ДСМ) з можливістю відновлення втраченої інформації, що не надходить своєчасно з технологічного обладнання до аналізуючих вузлів СОУ (рис. 1) по інформаційних каналах. Основною вимогою до такої моделі, окрім вищезазначених е здатність до повного чи часткового відновлення інформаціі. Одним із математичних апаратів, що відповідають вказаним критеріям є приховані марківські моделі [2].

(c) P.I. Дзінько, О.I. Лісовиченко, 2013 


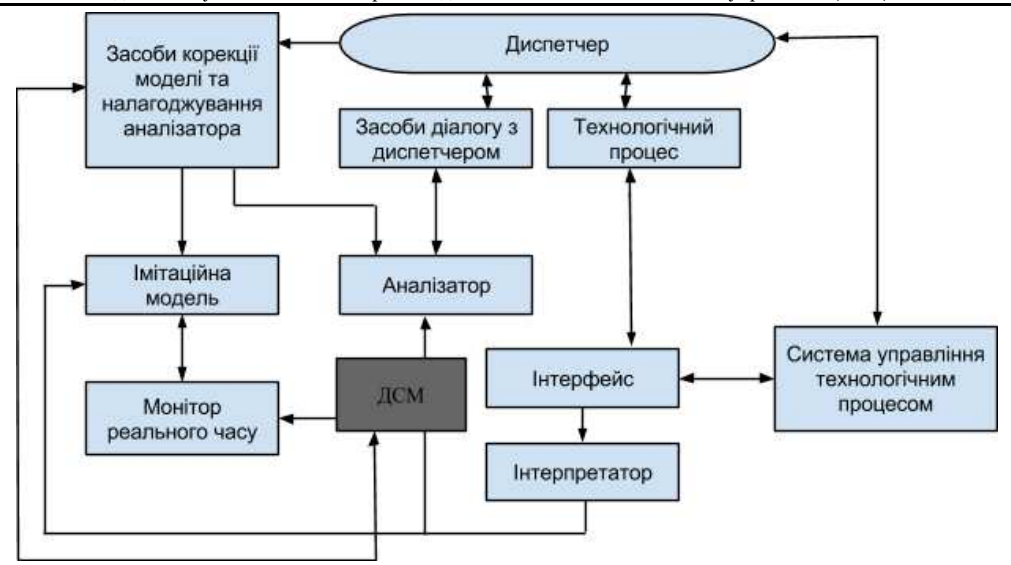

Рис. 1 - Структурна схема СОУ ГВС з дублюючою синхронною моделлю.

Використання марківських та напівмарківських процесів для моделювання ГВС є досить добре дослідженим. Приховані марківські моделі (ПММ) відрізняються від марківських процесів лише тим, що події в деяких вузлах ланцюжка є невідомими, чи прихованими [3], і виникає задача їх ідентифікації, тобто відновлення ланцюжка подій, що мав найвищу ймовірність відбутись.

\section{Постановка задачі}

Створити математичну модель дискретного виробництва з резервом часу та асинхронними автоматизованими лініями, як найбільш широко охоплюючий клас виробництв [1]. Інші підвиди виробництв пізніше можуть бути розглянуті як часткові випадки зазначеного класу.

Така математична модель в подальшому може використовуватись в якості засобу підвищення відмовостійкості фрункціонування виробничих систем, оскільки потенційно надає шляхи відтворення втраченої інформації з датчиків СОУ ГВС з синхронною моделлю, що, в свою чергу, допомагає визначити ступінь розсинхронізації реального перебігу виробництва з його моделлю, що відображає оперативний план, з ціллю прийняття рішень по оперативному управлінню.

При побудові СОУ ГВС з дублюючою синхронною моделлю, додаткова модель повинна володіти властивістю відновлення ланцюжка подій при умові, що деякі події невідомі.

Для того, що виконати цю задачу, необхідно для початку отримати приховану марківську модель гнучкої виробничої системи. 


\section{Структура ПММ}

ПММ виробничого процесу подається наступним чином:

$$
\lambda=\{S, \Omega, \Pi, A, B\}
$$

де $S=\left\{s_{1}, \ldots, s_{n}\right\}-$ кінцевий набір станів моделі ГВС, $\Omega=$ $\left\{\omega_{1}, \ldots, \omega_{n}\right\}-$ множина можливих подій, $\Pi=\left\{\pi_{1}, \ldots, \pi_{n}\right\}$ - початкові ймовірності виникнення подій, $A=\left\{a_{i j}\right\}$ - матриця переходів, $B=\left\{b_{i \omega_{k}}\right\}$ - ймовірність спостерігати подію $\omega_{k}$ після переходу системи в стан $s_{i}$.

Основними атомарними одиницями при моделюванні процесу виробництва є гнучких виробничий модуль (ГВМ), автоматизований склад (AC), автоматизований транспортний модуль (ATM). В деяких авторів також зустрічаються поняття технологічної комірки (ТК) чи гнучкої технологічної комірки (ГТК) [1]. В залежності від характеру виробництва та рівня абстракції моделі можна моделювати як кожен з вищеописаних типів елементів, так і обмежитий моделювання лише ГВМ, як основних вузлів моделі, а процес виробництва розглядати як зміну лише їх станів. В процесі моделювання виконуеться фіксація видимих подій, дані про які надаються датчиками, що входять до складу СОУ ГВС.

У випадку відсутності даних з датчиків в конкретний момент часу, скористаємось синхронною моделлю (наприклад, реалізованою у вигляді сітки Петрі), що відображає оперативний план роботи ГВС, для того, щоб отримати дані про те, яка подія мала б статися, і які події повинні вібдутись в системі наступними згідно плану.

В залежності від того, яка кількість датчиків та / чи каналів зв'язку, і в якій послідовності виходять з ладу, можна з відповідною ймовірністю дізнатись, чи дійсно відбулась в системі подія, яка була запланованою, чи ні.

Для вирішення ціеї задачі в якості основи можна прийняти алгоритм “взад-вперед” чи алгоритм Вітербі. В своему оригінальному варіанті вони застосовуються для визначення ланцюжка подій, який мав би відбутись з найбільш високою ймовірністю. Алгоритм Вітербі мітисть процедуру оберненого проходу, який використовується для фіксації ймовірностей конкретних подій, а тому може бути адаптований для вирішення поставленої задачі [3].

\section{Події, що фіксуються датчиками}

Вхідною інформацією для реестрації подій у вузлах ПММ $е$ інформація з датчиків, що розміщені на технологічному обладнанні (ТО): ГВМ та компонентах автоматизованої транспортноскладської системи (АТCC): автоматизованих транспортних модулях (ATM), конвеєрах, та автоматизованих складах (АC). 
Інформація з датчиків (сенсорів), що надходить, повинна інтерпретуватись в СОУ як певна подія, що відбулась на ТО, стан роботи якого моніториться вказаними датчиками.

Важливим аспектом інтерпретації даних е визначення кінцевої множини подій, що фіксуються для кожного конкретного ТО, оскільки зі збільшенням кількості подій значно збільшуеться час для виконання обчислень для деяких алгоритмів, що забезпечують роботу моделі, наприклад алгоритму повного перебору варіантів [3].

Для прикладу, множину подій, що можуть фіксуватись датчиками на АТМ (рис. 2), наведено в табл 1.
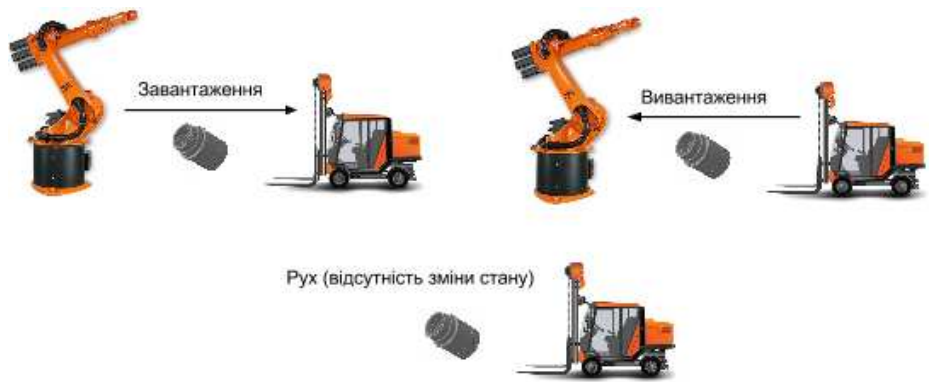

Рис. 2 - Множина подій, що можуть фіксуватись датчиками на ATM

Проте, в залежності від складності, та функцій, що забезпечуе технологічне обладнання, множина подій може бути розширена чи звужена. Також кожна подія повинна супроводжуватись часовим маркером, що вказуе момент часу, в який вона відбулась.

Таблиця 1

Пронумерована множина подій, що можуть бути зафіксованими на ATM

\begin{tabular}{|c|c|}
\hline Порядковий номер & Подія \\
\hline 1 & Завантаження деталі \\
\hline 2 & Вивантаження деталі \\
\hline 3 & Рух (відсутність зміни стану) \\
\hline
\end{tabular}

\section{Висновки}

Марківські та напівмарківські процеси успішно використовуються для моделювання дискретного виробництва з часовим резервом. В цій роботі продемонстрований підхід до моделювання виробництва з некласичним використанням прихованих марківських моделей в сукупності з імітаційною моделлю виробництва. 
Для прихованих марківських моделей існують алгоритми, що дозволяють відтворювати найбільш ймовірні ланцюжки подій за наявністю прихованих подій, що відбуваються в системі на базі так званих видимих подій, що фріксуються.

Існуючі алгоритми, як, наприклад, алгоритм Вітербі можуть застосовуватись також для визначення ймовірності настання прихованих подій з певною ймовірністю в залежності від об'єму втрачених даних.

В наступних роботах плануеться розробка такого алгоритму (чи групи алгоритмів), що вирішують поставлену задачу, а також перевірка достовірності відтворюваних даних в залежності від рівня інформаційних втрат.

\section{Біблиографічний список}

1. Копп В.Я. Моделирование автоматизированных производственных систем / В.Я. Копп. - Севастополь : СевНТУ, 2012 $700 \mathrm{c}$.

2. Дзінько P.І., Лісовиченко О.І. Система оперативного контролю виробництва з дублюючою синхронною моделлю / Р.І. Дзінько, О.І. Лісовиченко, АСАУ, 2013 № 1(22). - С. 10-16.

3. Rabiner L.R., Juang B.H. Introduction to Hidden Markov Models / L.R. Rabiner, B. H. Juang. - IEEE ASSP Magazine, January 1986.

Отримано 16.10.2013 p. 